\title{
Protein Kinase $(P K C)-\varepsilon$ Interacts with the Serotonin Transporter (SERT) C-Terminal Region
}

\author{
II Soo Moon ${ }^{1}$ and Dae-Hyun Seog* \\ Departments of Biochemistry, College of Medicine, Inje University, Busan 614-735, Korea \\ ${ }^{1}$ Departments of Anatomy, College of Medicine, Dongguk University, Gyeongju 780-714, Korea
}

Received August 6, 2010 / Accepted October 9, 2010

\begin{abstract}
Serotonin (5-hydroxytryptamine, 5-HT) is an important mediator of cell-cell signaling in neuronal systems. The serotonin transporter (SERT) on the plasma membrane controls the extracellular 5-HT level by reuptake of released 5-HT from the synaptic cleft, but the underlying regulation mechanism is unclear. Here, we used the yeast two-hybrid system to identify the specific binding protein(s) that interacts with the carboxyl (C)-terminal region of SERT and found a specific interaction with protein kinase C- $\varepsilon$ (PKC- $\varepsilon$ ), a PKC isotype that is characterized as a calcium-independent and phorbol ester/diacylglycerol-sensitive serine/threonine kinase. PKC- $\varepsilon$ bound to the tail region of SERT but not to other members of the $\mathrm{Na}^{+} / \mathrm{Cl}^{-}$dependent SLC6 gene family in the yeast two-hybrid assay. The C-terminal region of PKC- $\varepsilon$ is essential for interaction with SERT. In addition, these proteins showed specific interactions in the glutathione S-transferase (GST) pull-down assay. PKC- $\varepsilon$ phosphorylated the peptide of the SERT amino (N)-terminus in vitro. These results suggest that the phosphorylation of SERT by PKC-ع may regulate SERT activity in plasma membrane.
\end{abstract}

Key words : Serotonin, serotonin transporter, PKC-ع, protein-protein interaction, phosphorylation

\section{Introduction}

The neurotransmitter transporters are plasma membrane proteins that re-uptake extracellular neurotransmitters after release and thereby terminate the transmitter's action at extracellular receptor sites [2,31]. The tryptophan derivative 5-hydroxytryptamine (serotonin; 5-HT) is an important signaling molecule in the brain and periphery $[2,18]$. Like many other neurotransmitters, serotonin is predominantly inactivated by transporter-mediated clearance. The serotonin transporter (SERT) selectively transports 5-HT into nerve cells together with $\mathrm{Na}^{+}$and $\mathrm{Cl}^{-}$[31]. In neurons, SERT is predominantly localized in axon terminal membranes and present in low levels at the cell body and dendrite [2,35]. The primary function of SERT in the central nervous system involves the regulation of serotonergic signaling via transport of 5-HT molecules from the synaptic cleft into the pre-synaptic terminal for re-utilization [2]. SERT is also expressed in non-neuronal cells, including platelets, placental, intestinal and adrenal lines, but the extract function of SERT in these cell lines is still under investigation [9,35]. SERT is a member of sodium-dependent monoamine transporter

*Corresponding author

Tel : +82-51-890-6974, Fax : +82-51-894-5801

E-mail : daehyun@inje.ac.kr family, which also includes the dopamine transporter (DAT), $\gamma$-aminobutyric acid transporters (GATs), glycine transporter and norepinephrine transporter (NET) [2,9,31].

Topologically, SERT is an integral membrane protein comprised of twelve transmembrane domain and both the amino $(\mathrm{N})$ and carboxyl $(\mathrm{C})$ termini are exposed to the cytoplasm $[2,34]$. The N- and C-terminal cytoplasmic regions of SERT have recently increased attention for its importance in transport function and regulation $[17,21,34]$. The proteins interacting with the N-terminus of SERT are a-synuclein, Hic-5, secretory carrier membrane protein 2, and syntaxin 1A $[22,26]$. The C-terminus of SERT forms complexes with the MacMARCKS, actin cytoskeleton, neuronal nitric-oxide synthase, Sec23A, and Sec24C $[8,13,16,20]$, but the functional significance of these interactions are not known. Previous findings indicate that post-translational modifications by protein kinase play an important role in the regulation of neurotransmitter transporters $[12,19,28]$. Protein kinase dependent down-regulation has emerged as a common scheme for the modulation of neurotransmitter transporters [28]. SERT exhibits basal phosphorylation that can be elevated by activation of protein kinases and inhibition of protein phosphatase 2A [12]. Activation of protein kinase leads to an acute down-regulation of SERT-mediated 5-HT uptake [28]. This down-regulation is accompanied by a redistribution of 
the SERT from the cell surface to internal sites [19]. Recent reports show that cell surface levels of SERT can be regulated by protein kinase $\mathrm{G}$ (PKG) activation and p38 MAPK inactivation [36]. However, the phosphorylation of SERT has been demonstrated only by protein kinase A (PKA) and protein kinase $\mathrm{C}$ (PKC), but not PKG [3,4]. Recent evidence suggests that SERT is tightly regulated [19]. However, to date little is known about the mechanism and proteins involved in the regulation of SERT. To obtain further insight into the regulation of the SERT, we searched for proteins that directly interact with SERT. Here, we report that the intracellular C-terminal region of SERT interacts with the protein kinase C- $\varepsilon$ (PKC- $\varepsilon$ ), a member of the PKC family [1]. The SERTPKC- $\varepsilon$ interaction suggests that SERT may be subject to dynamic regulation by phosphorylation at the plasma membrane.

\section{Materials and Methods}

\section{Plasmid constructs}

Polymerase chain reaction (PCR) amplification was used to prepare the rat SERT cDNA (a gift of M. Setou of Hamamatsu University, Shizuoka, Japan). The C-terminal cytoplasmic region (amino acid; 594-630) of SERT was amplified by PCR and subcloned into pGEM T-easy vector (Promega Corp, Madison, WI, USA). All PCRs were carried out according to the standard protocol accompanying the enzymes Taq DNA polymerases (Stratagene, La Jolla, CA, USA). The fragment was then EcoRI-restricted and subcloned into the EcoRI site of pLexA (Clontech, Palo Alto, CA, USA). Glutathione S-transferase (GST) fusion constructs were generated by cloning the C-terminal cytoplasmic region of SERT, DAT, and NET cDNA into the GST fusion vector pET41 (Clontech). The correct orientation and in-frame cloning of cDNA inserts was verified by restriction enzyme analysis and DNA sequencing. The coding region of PKC- $\varepsilon$ was amplified by RT-PCR from mouse brain and cloned into pGEM T-easy vector. After EcoRI digestion, the PKC- $\varepsilon$ fragment was inserted into the EcoRI site of pB42AD (Clontech).

\section{Screening of SERT-binding protein by yeast two- hybrid screen}

A yeast two-hybrid cDNA library from mouse brain was obtained (Clontech), and host yeast strain (EGY48) used for the two-hybrid screenings was as described previously [14]. A yeast expression vector encoding a fusion protein of the
GAL4 binding domain and the C-terminal cytoplasmic region of SERT was constructed as follows. Base pairs 594-630 encoding the $36 \mathrm{C}$-terminal amino acids of the rat SERT were amplified from a pcDNA construct harboring the rat SERT cDNA by PCR. The constructed SERT bait plasmid DNA was transformed into yeast strain EGY48 carrying the p8op-lacZ gene. The EGY48 yeast cells containing the SERT bait plasmid were transformed with the cDNA library and grown on synthetic dextrose (SD) plates supplemented with glucose but with no histidine, tryptophan, or uracil (SD/-His/-Trp/-Ura). Positive colony was selected on SD lacking His, Trp, Ura, Leu containing galactose, raffinose, $\mathrm{X}$-gal, and BU salts. The candidate genes recovered after two-hybrid screening were isolated, sequenced, and retested for interaction with SERT in yeast by the retransformation. The isolated DNA sequence analysis was performed with the BLAST algorithm at the National Center for Biotechnology Information (NCBI).

\section{$\beta$-Galactosidase activity in liquid cultures of yeast}

The strength of the interactions between SERT and PKC- $\varepsilon$ constructs was assessed by measuring the $\beta$-galactosidase activity in liquid cultures. The $\beta$-galactosidase activity of the lacZ reporter gene was measured using o-nitrophenyl- $\beta$ -D-galactoside as a substrate as described previously [33]. In brief, mid-log phase transformed yeast cells were collected and permeabilized with $0.1 \%$ sodium dodecyl sulphate (SDS) and chloroform. An excess amount of chromogenic substrate o-nitrophenyl- $\beta$-D-galactoside was added to this lysate, and the mixture was incubated at $30^{\circ} \mathrm{C}$, and then the reaction was stopped by increasing $\mathrm{pH}$ to 11 by the addition of $1 \mathrm{M} \mathrm{Na}_{2} \mathrm{CO}_{3}$. The formation of the reaction product, o-nitrophenol, was determined by measuring absorbance at $420 \mathrm{~nm}$ on a spectrophotometer and normalizing for the reaction time and the cell density.

\section{Western blotting}

Detergent extracts were mixed with $5 \times$ SDS sample buffer, separated by $10 \%$ SDS-PAGE, and transferred onto nitrocellulose using a wet blot chamber (BioRad, München, Germany) containing transfer buffer $(0.25 \mathrm{M}$ Tris- $\mathrm{HCl}, \mathrm{pH}$ 8.3, $1.92 \mathrm{M}$ glycine, $1 \%$ (w/v) SDS, 20\% (v/v) methanol) as described in [32]. SERT fusion protein was detected with primary antibody. Bound antibody was visualized by using an enhanced chemiluminescence detection system (Pierce, Rockford, USA). 


\section{Glutathione S-transferase (GST) pull-down assays}

Pull-down assays using GST fusion proteins were performed as follows. cDNAs encoding the C-terminal cytoplasmic region of DAT (aa 577 to the carboxyl-terminus), NET (aa 489 to the carboxyl-terminus), GAT1 (aa 557 to the carboxyl-terminus), SERT (aa 594 to the carboxyl-terminus) and PKCs (aa 688 to the carboxyl-terminus) were cloned in pET 41, and the recombinant GST-DAT, NET, GAT1 and SERT fusion proteins were expressed in bacterial strain BL21 GOLD (Stratagene, La Jolla, CA, USA) after induction with $1 \mathrm{mM}$ isopropyl thio- $\beta$-D-galactopyranoside (Fisher Biotech, South Australia, Australia). BL21 GOLD expressing GST-fusion proteins were lysed in lysis buffer $(50 \mathrm{mM}$ Tris- $\mathrm{HCl}$ $\mathrm{pH} 7.4,25 \%$ sucrose, $1 \%$ Triton X-100, $5 \mathrm{mM} \mathrm{MgCl}$ containing $10 \mu \mathrm{g} / \mathrm{ml}$ each aprotinin, leupeptin, and pepstatin and $1 \mu \mathrm{M}$ phenylmethanesulfonyl fluoride). The fusion proteins were purified using glutathione-Sepharose 4B beads (Amersham Pharmacia Biotech, Piscataway, NJ, USA) by rotating for $1 \mathrm{hr}$ at $4^{\circ} \mathrm{C}$. After washing three times with $1 \%$ Triton X-100/phosphate-buffered saline, GST fusion protein-coupled Sepharose beads were mixed with $1 \mathrm{mg}$ of protein lysates prepared from mouse brain, which were pre-cleared with glutathione-Sepharose beads for $1 \mathrm{hr}$ at $4^{\circ} \mathrm{C}$. After rotating for $1 \mathrm{hr}$ at $4^{\circ} \mathrm{C}$, the GST fusion protein complex was washed five times with cell lysis buffer and subjected to immunoblotting.

\section{In vitro phosphorylation}

The phosphorylation activity of each kinase was measured the incorporated ${ }^{32} \mathrm{P}$ as described previously [10]. In brief, indicated protein kinases (50 ng) were incubated with $50 \mu \mathrm{M}$ of a peptide corresponding to the first 25 residues of rat SERT $\left(\mathrm{NH}_{2}\right.$-METTPLNSQKVLSECKDKEDCQENG- amide) in the presence of $10 \mathrm{mM} \mathrm{Mg}{ }^{2+}$ and $0.1 \mathrm{mM} \mathrm{[} \gamma$ $\left.{ }^{32} \mathrm{P}\right]$ ATP for $10 \mathrm{~min}$ at $30^{\circ} \mathrm{C}$. Note that the N-terminal peptide of the rat SERT contained two additional Arg residues at the C-terminal to facilitate its binding to the negatively charged filter. After the incubation the mixture was filtered, washed, and counted for incorporated ${ }^{32} \mathrm{P}$.

\section{Results}

\section{Identification of SERT interacting proteins by yeast two-hybrid screening}

The cytoplasmic 20 amino acids of the C-terminal region of SERT are critical for the regulation of the transporter activity [17]. However, the role of this region on the protein-protein interactions of SERT is incompletely understood. To examine SERT-interacting proteins, we have used the yeast two-hybrid system to search for novel regulatory proteins that interact with the C-terminal cytoplasmic region of SERT. From $5 \times 10^{6}$ colonies screened, we obtained five positive clones. Two clones (clone 2, and 5) were fragments of PKC- $\varepsilon$ containing the C-terminal region (Fig. 1). Retransformation experiments with the yeast two-hybrid system showed that the C-terminal region of PKC- $\varepsilon$ supported growth of the yeast on nutrient-deficient media, indicating that the $\mathrm{C}$-terminal region mediated this interaction (Fig. 1). PKC- $\varepsilon$ consists of an N-terminal C2 domain (previously termed as the D1 or V1 region), followed by a kinase domain [1]. To determine the minimal binding region of PKC- $\varepsilon$ required for the interaction with SERT, we constructed deletion mutants of PKC- $\varepsilon$ and analyzed their interactions with SERT using the yeast two-hybrid assay. Only the C-terminus region of PKC- $\varepsilon$ interacted with SERT in the yeast two-hybrid assay, as shown in Fig. 1. These data in-

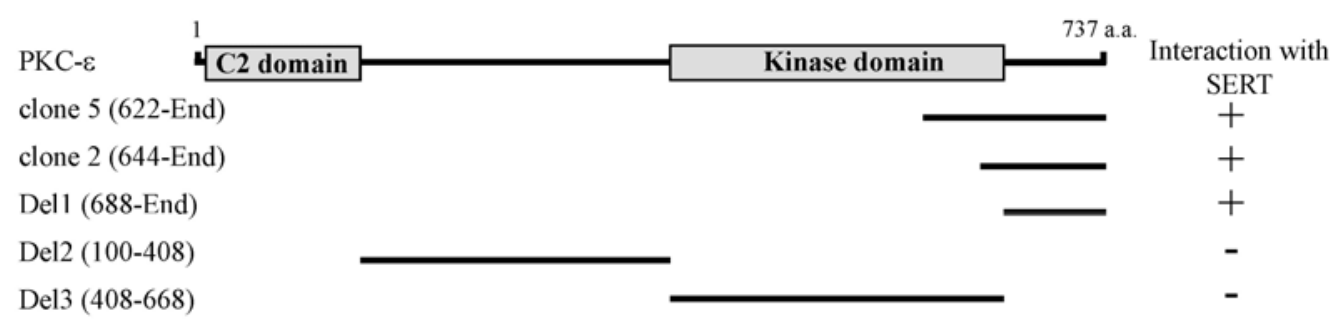

Fig. 1. Identification of the proteins interacting with SERT by yeast two-hybrid screening. Minimal SERT binding region in PKC-ع. PKC- $\varepsilon$ has C2 domain and kinase domain. C2 and kinase domains are indicated in gray. a.a, the amino acid residue number. Clone 2 and 5, which were isolated from the yeast two-hybrid screen, overlapped at the C-terminal region of PKC- $\varepsilon$. Different truncations of PKC- $\varepsilon$ were constructed by PCR. Several truncated forms of PKC- $\varepsilon$ were tested in the yeast two-hybrid assays for interaction with SERT. +++, interaction with SERT; -, no interaction with SERT. 
dicates that SERT specifically binds to the C-terminal region of PKC- $\varepsilon$.

\section{PKC- $\varepsilon$ binds specifically to SERT}

SERT belongs to the $\mathrm{Na}^{+} / \mathrm{Cl}^{-}$dependent SLC6 gene family, which also includes DAT, NET, and GATs [34]. In order to confirm whether PKC- $\varepsilon$ interacts with other SLC6 gene family, we performed yeast two-hybrid assays. When the C-terminal cytoplasmic regions of NET, DAT, SERT and GAT1 were tested for PKC- $\varepsilon$-binding by yeast two-hybrid assays, there was no detectable binding between PKC- $\varepsilon$ and the C-terminal cytoplasmic regions of NET, DAT and GAT1 (Fig. 2A). These data indicate that the interaction of PKC- $\varepsilon$ with SLC gene family is specific to SERT. To quantify the binding strength of PKC- $\varepsilon$ to SERT, the bait plasmids of SERT, DAT, GAT1 and PKC- $\varepsilon$ were transformed to yeast and were measured using $\beta$-galactosidase activity in liquid cultures. The interaction of SERT with PKC- $\varepsilon$ yielded approximately 391 units of $\beta$-galactosidase activity (Fig. 2B), reflecting a binding strength that is sufficient to protein-protein interaction in vivo [33].

\section{PKC- $\varepsilon$ associate with the SERT C-terminus}

In order to determine whether PKC- $\varepsilon$ directly interacts with SERT, we performed GST pull down assays. The C-terminal cytoplasmic region of SERT and other SLC6 gene family were expressed as GST fusion proteins in E. coli. These
A)

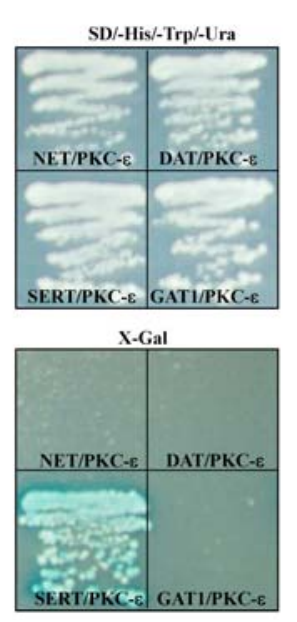

B)

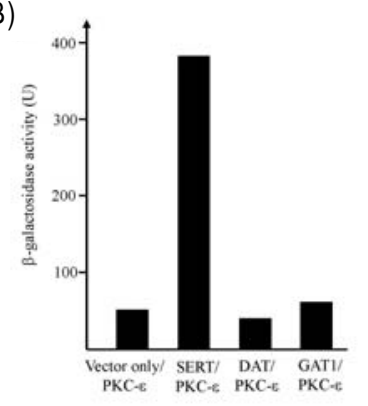

Fig. 2. Interaction between SERT and PKC-ع. (A) The C-terminal regions of SLC6 gene family were fused to the pLexA DNA binding domain. PKC- $\varepsilon$ specifically interacted with SERT but not with NET, DAT or GAT1. (B) The quantification of $\beta$-galactosidase activity in yeast cells resulting

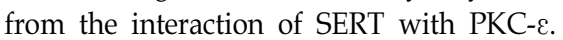

GST-fusion proteins were immobilized on glutathioneSepharose beads, and incubated with mouse whole brain lysates. Immunoblot analysis of the pull-down proteins showed that PKC- $\varepsilon$ interacted with SERT. In contrast, GST fusion proteins containing the $\mathrm{C}$-terminal cytoplasmic region of the DAT, NET, and GAT1 failed to pull down PKC- $\varepsilon$ (Fig. 3A). The C-terminal GST fusion proteins containing either the last 37 residues (GST-SERT (594-630)) or the last 24 residues (GST-SERT (607-630)) of SERT were capable of pulling down with PKC- $\varepsilon$. In contrast, GST itself and a fusion protein encoding the N-terminus of SERT (amino acids 1-25) did not bind with PKC-ع.Also, deleting the 23 C-terminal residues of this fusion protein (GST-SERT (594-607)) failed to pull down PKC- $\varepsilon$ (Fig. 3B). We further confirmed the structural requirements of the $\mathrm{PKC}-\varepsilon$ for interaction with SERT in GST pull-down experiment. As shown in Fig. 3C, a C-terminal fusion encoding the 49 residues (Del1) of PKC- $\varepsilon$ was capable of pulling down SERT. However, Del2 and Del3, which are devoid of C-termini did not pull down SERT, These data are consistent with the yeast two-hybrid

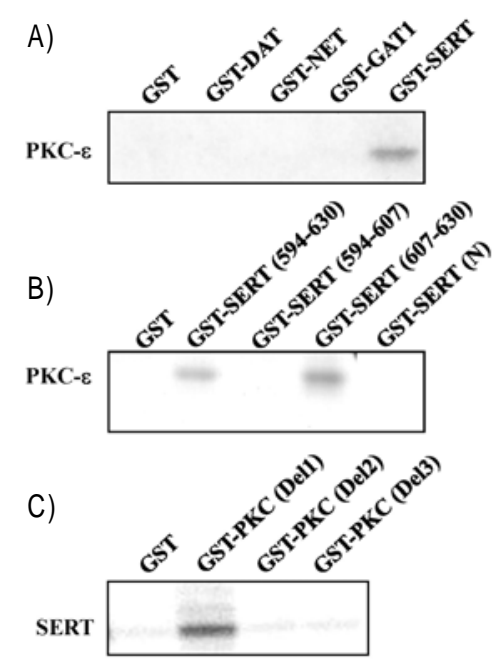

Fig. 3. Association of SERT with PKC- $\varepsilon$ in the pull-down assay. (A) Association of PKC- $\varepsilon$ and SLC6 gene family in the GST pull-down assay. Proteins in the mouse brain lysate were allowed to bind to GST alone, GST-DAT, GST-NET, GST-GAT1, or GST-SERT fusion proteins. The elution fractions were resolved by SDS-PAGE and immunoblot analysis was performed using an antibody

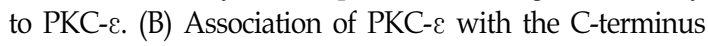
of SERT. Several deletion forms of SERT were tested in the GST pull-down assay for interaction with PKC-ع. The N-terminal fusion protein (N, amino acid; 1-26). (C) Interaction of SERT with the C-terminal of PKC- $\varepsilon$. Several deletion forms of PKC- $\varepsilon$ were tested in the GST pull-down assays for interaction with SERT. 


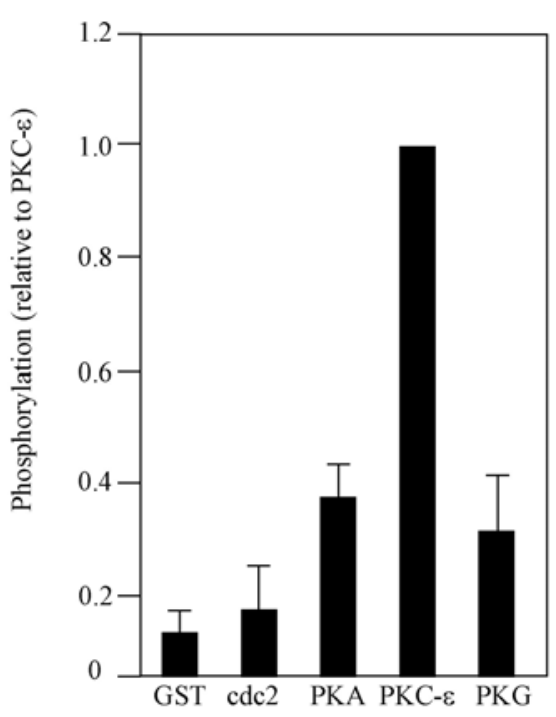

Fig. 4. PKC- $\varepsilon$ phosphorylates the SERT $\mathrm{N}$ terminus in vitro. The relative phosphorylation efficiency of an $\mathrm{N}$-terminal SERT peptide (residues 1-25) is shown for different kinases as described in Materials and Methods. The data are expressed as phosphorylation relative to a known substrate peptide of PKC- $\varepsilon$. The data are averages of two assays.

assay results, and indicate that SERT directly interacts with PKC- $\varepsilon$ and the C-terminal regions of SERT, and PKC- $\varepsilon$ are essential for interaction with SERT and PKC-ع.

\section{PKC- $\varepsilon$ phosphorylates the SERT N-terminus}

SERT has consensus sequences for potential phosphorylation sites by PKC- $\varepsilon$ [7]. In previous studies, several protein kinase could phosphortlate the serine residues of SERT N-terminal [29]. To clarify whether PKC- $\varepsilon$ directly phosphorylates the SERT, we tested the ability of PKC- $\varepsilon$ to incorporate phosphate into a peptide corresponding to the first N-terminal 25 residues of SERT. The efficiency of PKA phosphorylation of the SERT peptide was $38 \%$ of that of the PKC$\varepsilon$. In comparison, PKG phosphorylated the peptide with an efficiency of $34 \%$. In contrast, none of the GST only and cdc2 tested incorporated significant phosphate into the N-terminal peptide of SERT (Fig. 4). Thus, at least in vitro, the N-terminal region of SERT subserves a substrate for PKC-ع.

\section{Discussion}

The N- and C-terminal domains of SERT are thought to be located in the cytoplasm and they also contain a number of potential phosphorylation sites $[7,15,18]$. These domains are the most likely binding sites for directly interacting, po- tential regulatory proteins [2,6]. In order to identify novel SERT binding proteins, we performed a yeast two-hybrid screen with the C-terminal cytoplasmic region of SERT. In this study we demonstrate for the first time that the SERT directly interacts with PKC- $\varepsilon$. First, we showed that PKC- $\varepsilon$ interacts with SERT in the yeast two-hybrid system (Fig. 1). Secondly, we demonstrated the interaction of PKC- $\varepsilon$ with the C-terminal cytoplasmic region of SERT in GST pulldown assay (Fig. 3A, 3B). Furthermore our results also demonstrated that PKC- $\varepsilon$ could phosphorylate in vitro a synthetic SERT N-terminal peptide (Fig. 4).

Protein phosphorylation is a central mechanism involved in the short-term regulation of cellular processes [15]. The function of sodium-dependent monoamine neurotransmitter transporters is regulated by phosphorylation/dephosphorylation [27,34]. SERT also has consensus sequences for potential phosphorylation sites by protein kinases $[6,20]$. In many pharmacological studies, SERT uptake activity was shown to be modulated by PKA, PKC and other protein kinases $[25,27,29]$. Activation of PKA has been shown to up-regulate the transport activity of the SERT via increased synthesis of the SERT, rather than the direct phosphorylation of the SERT [5,20]. In contrast, the activation of PKC by phorbol esters resulted in a reduction of serotonin uptake in endothelial cells, platelets, and RBL cells [3,20,23]. In another report, PKC activation resulted in reducing the numbers of SERT in the cell surface using biotinylation analyses [25]. This finding suggests that PKC activation may induce redistribution of the SERT and regulate its activity by altering the protein trafficking system or internalization [19]. However, the detailed mechanism of the involvement of PKC in this inhibitory modulation of SERT activity is unclear.

Our results showed that PKC- $\varepsilon$ directly phosphorylates the N-terminal region of SERT. An interesting question is how N-terminal phosphorylation of SERT regulates the activity of SERT. In previous pharmacological studies, the recombinant SERT expressed in cells failed to reveal changes in substrate transport after PKA activation, and stimulation of PKC has been shown to result in a reduction of maximal transport activity without alterations in substrate affinity $[25,29]$. This decrease of maximal transport activity is a consequence of SERT internalization from the plasma membrane into endocytosis vesicles [9]. In previous results, the phosphorylation-mediated reduction of serotonin uptake was found to be maintained even upon mutation of all pre- 
dicted phosphorylation sites in the SERT polypeptide [29]. Therefore, internalization by phosphorylation may not result from direct phosphorylation of SERT, but involves indirect mechanism. Additionally, previous result suggested that the phosphorylation-mediated reduction in SERT activity results in part from the disruption of F-actin and resulting morphological changes in cellular organization [30]. PKC- $\varepsilon$ is the most abundant isotype in the central nervous system [1]. Several proteins important for neuronal signal transduction interact with PKC- $\varepsilon$ [1]. PKC- $\varepsilon$ induces neurite outgrowth during neuronal differentiation activated by various stimuli through interaction with actin filament [11]. The significance of the actin-binding site in the interaction with filaments has been implicated in neurotransmitter endocytosis [24]. Recruitment of PKC- $\varepsilon$ by binding to the C-terminal cytoplasmic region of SERT and its phosphorylation of the N-terminal region of SERT may provide important clues to these phenomena.

\section{References}

1. Akita, Y. 2002. Protein kinase C-epsilon (PKC-epsilon): its unique structure and function. J. Biochem. 132, 847-852.

2. Amara, S. G. and M. J. Kuhar. 1993. Neurotransmitter transporters: recent progress. Annu. Rev. Neurosci. 16, 73-93.

3. Anderson, G. M. and W. C. Horne. 1992. Activators of protein kinase $C$ decrease serotonin transport in human platelets. Biochim. Biophys. Acta. 1137, 331-337.

4. Barker, E. L., M. A. Perlman, E. M. Adkins, W. J. Houlihan, Z. B. Pristupa, H. B. Niznik, and R. D. Blakely. 1998. High affinity recognition of serotonin transporter antagonists defined by species-scanning mutagenesis. An aromatic residue in transmembrane domain I dictates species-selective recognition of citalopram and mazindol. J. Biol. Chem. 273, 1945919468.

5. Benmansour, S., M. Cecchi, D. A. Morliak, G. A. Gerhardt, M. A. Javors, G. G. Gould, and A. Frazer. 1999. Effects of chronic antidepressant treatments on serotonin transporter function, density, and mRNA level. J. Neurosci. 19, 1049410501.

6. Bjerggaard, C., J. U. Fog, H. Hastrup, K. Madsen, C. J. Loland, J. A. Javitch, and U. Gether. 2004. Surface targeting of the dopamine transporter involves discrete epitopes in the distal $\mathrm{C}$ terminus but does not require canonical PDZ domain interactions. J. Neurosci. 24, 7024-7036.

7. Blakely, R. D., H. E. Berson, R. T. Fremeau Jr, M. G. Caron, and M. M. Peek, H. K. Prince, and C. C. Bradley. 1991. Cloning and expression of a functional serotonin transporter from rat brain. Nature 354, 66-70.

8. Carneiro, A. M. and R. D. Blakely. 2006. Serotonin-, protein kinase C-, and Hic-5-associated redistribution of the platelet serotonin transporter. J. Biol. Chem. 281, 24769-24780.

9. Chen, N. H., M. E. Reith, and M. W. Quick. 2004. Synaptic uptake and beyond: the sodium- and chloride-dependent neurotransmitter transporter family SLC6, Pflugers Arch. 447, 519-531.

10. Fog, J. U., H. Khoshbouei, M. Holy, W. A. Owens, C. B. Vaegter, N. Sen, Y. Nikandrova, E. Bowton, D. G. McMahon, R. J. Colbran, L. C. Daws, H. H. Sitte, J. A. Javitch, A. Galli, and U. Gether. 2006. Calmodulin kinase II interacts with the dopamine transporter $\mathrm{C}$ terminus to regulate amphetamine-induced reverse transport. Neuron 51, 417-429.

11. Hundle, B., T. McMahon, J. Dadgar, and R. O. Messing. 1995. Overexpression of epsilon-protein kinase $C$ enhances nerve growth factor-induced phosphorylation of mitogen-activated protein kinases and neurite outgrowth. J. Biol. Chem. 270, 30134-30140.

12. Jayanthi, L. D., D. J. Samuvel, R. D. Blakely, and S. Ramamoorthy. 2005. Evidence for biphasic effects of protein kinase $\mathrm{C}$ on serotonin transporter function, endocytosis, and phosphorylation. Mol. Pharmacol. 67, 2077-2087.

13. Jess, U., O. El Far, J. Kirsch, and H. Betz. 2002. Interaction of the C-terminal region of the rat serotonin transporter with MacMARCKS modulates 5-HT uptake regulation by protein kinase C. Biochem. Biophys. Res. Commun. 294, 272-279.

14. Kim, S. J., C. H. Lee, H. Y. Park, S. S. Yea, W. H. Jang, S. K. Lee, Y. H. Park, O. S. Cha, I. S. Moon, and D. H. Seog. 2007. JSAP1 interacts with kinesin light chain 1 through conserved binding segments. J. Life Sci. 17, 889-895.

15. Krebs, E. G. and J. A. Beavo. 1979. Phosphorylation-dephosphorylation of enzymes. Annu. Rev. Biochem. 48, 923-959.

16. Kusumi, A. and Y. Sako. 1996. Cell surface organization by the membrane skeleton. Curr. Opin. Cell Biol. 8, 566-574.

17. Larsen, M. B., A. W. Fjorback, and O. Wiborg. 2006. The C-terminus is critical for the functional expression of the human serotonin transporter. Biochemistry 45, 1331-1337.

18. Lesch, K. P., B. L. Wolozin, H. C. Estler, D. L. Murphy, and P. Riederer. 1993. Isolation of a cDNA encoding the human brain serotonin transporter. J. Neural. Transm. Gen. Sect. 91, 67-72.

19. Melikian, H. E. 2004. Neurotransmitter transporter trafficking: endocytosis, recycling, and regulation. Pharmacol. Ther. 104, 17-27.

20. Miller, J. and B. J. Hoffman. 1994. Adenosine A3 receptors regulate serotonin transport via nitric oxide and cGMP. J. Biol. Chem. 269, 27351-27356.

21. Mochizuki, H., T. Amano, T. Seki, H. Matsubayashi, C. Mitsuhata, K. Morita, S. Kitayama, T. Dohi, H. K. Mishima, and N. Sakai. 2005. Role of C-terminal region in the functional regulation of rat serotonin transporter (SERT). Neurochem. Int. 46, 93-105.

22. Muller, H. K., O. Wiborg, and J. Haase, J. 2006. Subcellular redistribution of the serotonin transporter by secretory carrier membrane protein 2. J. Biol. Chem. 281, 28901-28909.

23. Myers, C. L., J. S. Lazo, and B. R Pitt. 1989. Translocation of protein kinase $\mathrm{C}$ is associated with inhibition of $5-\mathrm{HT}$ 
uptake by cultured endothelial cells. Am. J. Physiol. 257, L253-258.

24. Prekeris, R., M. W. Mayhew, J. B. Cooper, and D. M. Terrian. 1996. Identification and localization of an actin-binding motif that is unique to the epsilon isoform of protein kinase $\mathrm{C}$ and participates in the regulation of synaptic function. J. Cell Biol. 132, 77-90.

25. Qian, Y., A. Galli, S. Ramamoorthy, S. Risso, L. J. De Felice, and R. D. Blakely. 1997. Protein kinase C activation regulates human serotonin transporters in HEK-293 cells via altered cell surface expression. J. Neurosci. 17, 45-57.

26. Quick, M. W. 2002. Role of syntaxin 1A on serotonin transporter expression in developing thalamocortical neurons. Int. J. Dev. Neurosci. 20, 219-224.

27. Quick, M. W. 2003. Regulating the conducting states of a mammalian serotonin transporter. Neuron 40, 537-549.

28. Rudnick, G. and J. Clark. 1993. From synapse to vesicle: the reuptake and storage of biogenic amine neurotransmitters. Biochim. Biophys. Acta. 1144, 249-263.

29. Sakai, N., K. Sasaki, M. Nakashita, S. Honda, N. Ikegati, and N. Saito. 1997. Modulation of serotonin transporter activity by a protein kinase $\mathrm{C}$ activator and an inhibitor of type 1 and 2A serine/threonine phosphatases. J. Neurochem. 68, 2618-2624.

30. Sakai, N., N. Kodama, S. Ohmor, K. Sasaki, and N. Saito. 2000. Involvement of the actin cytoskeleton in the regulation of serotonin transport SET activity: possible mechanism un- derlying SET regulation by protein kinase C. Neurochem. Int. 36, 567-579.

31. Schloss, P., A. W. Püschel, and H. Betz. 1994. Neurotransmitter transporters: new members of known families. Curr. Opin. Cell Biol. 6, 595-599.

32. Sur, C., H. Betz, and P. Schloss. 1998. Distinct effects of imipramine on 5-hydroxytryptamine uptake mediated by the recombinant rat serotonin transporter SERT1. J. Neurochem. 70, 2545-2553.

33. Takeda, S., H. Yamazaki, D. H. Seog, Y. Kanai, S. Terada, and N. Hirokawa. 2000. Kinesin superfamily protein 3 (KIF3) motor transports fodrin-associating vesicles important for neurite building. J. Cell Biol. 148, 1255-1265.

34. Torres, G. E., R. R. Gainetdinov, and M. G. Caron. 2003. Plasma membrane monoamine transporters: structure, regulation and function. Nat. Rev. Neurosci. 4, 13-25.

35. Zhou, F. C., Y. Xu, S. Bledsoe, R. Lin, and M. R. Kelley. 1996. Serotonin transporter antibodies: production, characterization, and localization in the brain. Brain Res. Mol. Brain Res. 43, 267-278.

36. Zhu, C. B., W. A. Hewlett, I. Feoktistov, I. Biaggioni, and R. D. Blakely. 2004. Adenosine receptor, protein kinase G, and p38 mitogen-activated protein kinase-dependent up-regulation of serotonin transporters involves both transporter trafficking and activation. Mol. Pharmacol. 65, 14621474.

\title{
초록 : Protein kinase (PKC)- $\varepsilon$ 와 serotonin transporter (SERT)의 C-말단과의 결합
}

\author{
문일수 ${ }^{1} \cdot$ 석대현* \\ (인제대학교 의과대학 생화학교실, ${ }^{1}$ 동국대학교 의과대학 해부학교실)
}

Serotonin (5-hydroxytryptamine (5-HT))는 신경계의 세포-세포 간의 신호전달의 주요한 신경전달물질이다. 세포막 에 존재하는 serotonin transporter (SERT)는 연접간격에 존재하는 5-HT를 세포 내로 재흡수 하여 세포외부의 5-HT 농도를 조절하지만 그 기전은 아직 밝혀지지 않았다. 본 연구에서는 yeast two-hybrid system을 사용하여 SERT의 C-말

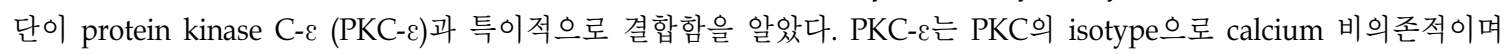
phorbol ester/diacylglycerol 민감성 serine/threonine kinase이다. $\mathrm{Na}^{+} / \mathrm{Cl}^{-}$의존성 SLC6 gene family의 다른 수송체는

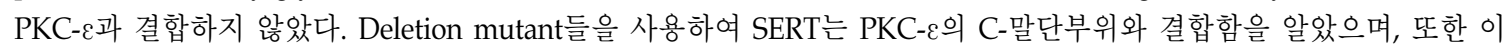
단백질간의 결합을 GST pull-down assay로 확인하였다. PKC-8는 in vitro에서 SERT의 $\mathrm{N}$-말단의 펩티드를 인산화시켰 다. 이러한 결과들은 PKC-\&에 의한 SERT의 인산화가 세포막에 존재하는 SERT의 활성을 조절하는 역할을 할 가능성을 시사한다. 